tese sustentada pelos ilustres juristas argentinos, entende que, hoje, ainda não há oportunidade de regular, no Direito do Trabalho, tôdas as três formas de trabalho humano. Na sua obra, êste emérițo jurista reconhece que "o horizonte e o conceito lógico que se descortina pode parecer demasiado vasto". Significa, que êle próprio, ardoroso defensor desta tese, entende que, ainda presentemente, não é possível que o Direito do Trabalho abranja e regule estas três atividades humanas.

De maneira que, na Comissão de que faço parte, tomei a liberdade de fazer pequeno reparo à conclusão dos ilustres e renomados juristas argentinos e, na proposição que êles fizeram presente ao Congresso Jurídico, me permiti acrescentar o seguinte: "que o Congresso declara que tôda relação jưrídica oriunda do trabalho subordinado deve ser regida por normas do Direito do Trabalho". Implica isso em dizer que o trabalho objeto do contrato individual, em tôda sua plenitude, é abrangido pelo Direito do Trabalho, mesmo a atividade dos trabalhadores rurais e, ainda, a dos empregados domésticos hoje reguladas apenas em parte. Os trabalhadores rurais, no Brasil, apenas têm direito a aviso prévio, a férias e contrato de trabalho. Os empregados domésticos, hoje, estão fora do nosso Direito, por isto que o decreto 3.078 , como não foi regulamentado não está mais em vigência e foi abolido em nosso meio.

De maneira, que a recomendação - que foi aprovada unanimemente na minha Comissão, e que faço presente a êste Congresso, é que, com esta modificação, êle declare que apenas o trabalho subordinado seja regido pelo Direito do Trabalho.

Era o que eu tinha a dizer a êste respeito. (Palmas).

\title{
A PRESCRIÇÃO NO DIREITO DO TRABALHO
}

\section{Mozart Victor Russomano}

Professor da Faculdade de Direito de Pelotas (Universidade do Rio Grande do Sul).

Juiz do Trabalho. Membro Titular da Soceidade Internacional de Direito Social.

\section{1 - O DIREITO DO TRABALHO COMO RAMO DA CIENCIA JURÍDICA.}

O Direito do Trabalho é uma ponta de lança da ciência jurídica a tocar o cerne do problema das "classes" e procurando, em nome do Estado, a solução da luta milenária que se trava entre elas, solução essa colocada numa geral conciliação dos espíritos e dos interêsses desarmados.

O desenvolvimento extraordinário do Direito do Trabalho, no século em que vivemos, resulta do ápice a que chegaram os sociólogos, os moralistas, os filósofos, os juristas e os políticos na sua preocupação muito humana de defender a massa que trabalha, que sofre, que pouco rendimento obtém e que constitui a maioria do povo.

Êsse desenvolvimento se fêz em todos os sentidos. Para explicá-lo, é preciso alinhar uma longa série de fundamentos. A religião, a ciência, a moral, a administração pública, a política e tantos outros fatôres impulsionaram o legislador, que compôs uma farta coletânea de leis em tôrno das questóes que se enovelam no debate dos vínculos criados entre empregado e empregador na prestação de servicos. A abundância de dispositivos sôbre o assunto lhe deu alto valor científico, pelo significado jurídico-social das relações humanas entre o patrão e o empregado; e didático, pelo valor que hoje tem, para o profissional do forum, uma visão plástica e exata das equacões sociais. Exigiu-se, assim, um estudo especializado do Direito do Trabalho.

A primeira idéia foi um sonho de solidariedade espontânea e desinteressada.

O homem explorado pelo homem foi o axioma vencido nas lutas políticas de vários séculos. 
Essa fisionomia solidarista do Direito do Trabalho, que o fundamentou a princípio, até hoje o inspira, forçando o legislador, que cria o direito positivo; o juiz, que o aplica; o jurista, que o analisa e critica, a que submetam o assunto versado ao princípio de proteção do "hipossuficiente" (CESARINO JUNIOR).

O sentimento de proteção foi, com os tempos, superado. "La tutela della classe lavoratrice, - escreve LIONELLO R. LEVI oggetto della legislazione sociale, viene attuata in vista del perseguimento di alcuni interessi che lo Stato ha assunto tra i propri fini: interessi di ordine demográfico, di sanità della stirpe, di elevazione morale e materiale dei lavoratori. Veramente la dottrina meno recente era solita porre in maggiore rilievo la finalità meramente protettiva del lavoratore, considerato come il soggetto più debole - e quindi bisognoso di protezione e di tutela - nella formazione e nello svolgimeno del rapporto di lavoro. Ora, che tale - finalità fosse presente al legislatore, specie nei primordi della legislazione sociale, è indubbio; ma è indubbio altrersì che non è mai stata essa la finalità ultima, la quale era invece rappresentata da scopi di interesse più generale e di natura nettamente pubblicistica" $\left({ }^{1}\right)$.

Hoje, o Direito do Trabalho, antes de tudo, visa à conciliação das classes através de uma proteção eficiente ao que trabalha. Para isso, possuí o seu método particular, que é o "critério sociológico", que faz com que o intérprete encare o Direito através da vida e das últimas verificações da Sociologia Geral.

O Direito vinha, desde a alelúia sangrenta da Revolução Francesa, calcado em alguns princípios individualistas.

Contra êsse estado de coisas, o Direito do Trabalho valeu por uma reação.

O sentimento de coletividade, que desde o século XIX está trabalhando pelo entendimento dos homens, ora nas escarpadas do pensamento marxista, ora nas doces colinas da teoria de Leão XIII, se opôs ao individualismo dominante, que ainda trabalha em favor do cidadão e de sua liberdade pessoal, permitindo o choque das concorrências, o contraste das intenções e o livre curso dos apetites. O trabalhador, "sujeto durante varios siglos a un régimen de compresión se emancipó con la Revolución Francesa; pero como la libertad trajo consigo el aislamento del obrero y su impotencia frente a las concentraciones del capital, el Estado se vió precisado a intervenir para protegerlo contra las exacciones de las grandes empresas" $\left({ }^{2}\right)$.

Um dos caracteres peculiares do Direito do Trabalho, portanto, o fundamental, está em colocar êle o interêsse da coletividade acima do interêsse particular de "A" ou de "B".

(1) "Instituzioni di Legislazione Sociale", pág. 4, 1.947, Milano. (2) DANIEL ANTOKOLETZ, "Curso de Legislacion del Trabajo", 1.0 vol.,
páo. 9, 1.927, Buenos Aires.
O social através do trabalhador. - Eis uma fórmula viável.

A proteção que o Direito do Trabalho dá ao empregado é, primeiramente, u'a medida justa. Uma recompensa. Uma compensação, após tantos séculos de serviço escravo ou servil. Aquela proteção não é, todavia, cientificamente, dada pelo interêsse moral de protegermos o nosso semelhante ou pelas conveniências políticas de satisfazermos a vontade da maioria popular.

Superando a todos êsses fatôres, como fundamentação última da existência do Direito do Trabalho, está o interêsse coletivo. Se tudo hoje se faz ou se procura fazer para elevação do nível mental e vital dos proletários, a consequência dêsse modo de encarar o problema da sociedade é a criação de um ambiente coletivo mais elevado. Graças àquelas ações e reações de que nos fala GOËTHE, tanto quanto o trabalhador, com as medidas a seu favor, lucra a comunidade, porque ela assim sobe um degráu a mais. Embora indiretamente, todos os membros do grupo gozam dos benefícios da proteção ao trabalhador.

A subsistência e a felicidade do grupo social dependem do maior estreitamento dos laços que unem seus componentes. Sem paz não pode haver evolução, nem vida nacional. Não há paz quando, nos subterrâneos, fermentam ódios e incompatibilidades, sobretudo se êles reciprocamente se descarregam de parte das duas grandes classes - operário e patrão - que formam as paralelas da sociedade no século XX e que, até hoje, permanecem submetidas à fatalidade geométrica de não se encontrarem nunca, a não ser no infinito das utopias.

O interêsse do empregado é a coluna mais alta dentro do campo jurídico do trabalho. Como pilastra, porém, está amparando a cúpola suprema do interêsse coletivo. "Il rapporto di lavoro è fondamentalmente rapporto di diritto privato, ma il rapporto stesso há, per molt lati, una disciplina obbligatoria inderogabile, limitatrice, cioè, della libertà individuale per fini d'interesse sociale" $\left({ }^{3}\right)$.

$O$ direito positivo brasileiro aceitou a lição uniforme da doutrina italiana, quando lançou o art. $8^{\circ}$, da Consolidação das Leis do Trabalho, que sujeita qualquer decisão da Justiça do Trabalho ou das autoridades administrativas a um critério de prevalência dos interêsses públicos, postos acima de qualquer interêsse particular ou de classe.

Todo apoio dado ao empregado transcende as finalidades éticas da solidariedade, para existir em função das necessidades coletivas, especialmente como meio de pacificação social.

A intervenção do Estado na vida trabalhista se acentua cada vez mais, pelos motivos expostos.

(3) FERRUCIO PERGOLESI, "Diritto del Lavoro", pág. 11, 1.949, Bologna. 
Conforme assevera POZZO, "el siglo XIX ofrece una curiosa contradicción entre los principios politicos y los economicos que do minaron. Mientras los primeros tendieron a destacar la personalidad del individuo, a exaltarla, a consagrar su libertad y declarar la igualdad de todos los hombres ante la ley, la economía, en virtud precisamente de la libertad y de la igualdad, consagraba la sujeición del tra bajador, que contaba solo con sus fuerzas y su actividad para vivi al servicio de quien disponía del capital capaz de poner en movimiento la industria" ( $\left.{ }^{4}\right)$.

A inclinação social do Direito, cada vez mais sensível e irresistî vel, coloca o Estado acima do Cidadão, a Sociedade acima do Homem, porque o primeiro encarna a vontade coletiva e o segundo representa uma só vontade.

O Direito do Trabalho espelha, melhor que qualquer outro ramo da ciência jurídica, êsse aspecto moderno da atuação do Estado.

Representa essa faceta a vitória das escolas chamadas socialìsta. sôbre a escola liberal. A oposição entre as duas opiniões sempre foi absoluta. Esta afastando o Estado da regulamentação dos contratos de trabalho. Aquela chamando-o a intervir nos pactos laborais e impondo regras de defesa do trabalhador e da sociedade (5).

$O$ Direito do Trabalho, portanto, assenta em raizes de alto alcance científico e filosófico. Como diz CESARINO JUNIOR, "ao logicismo do antigo direito, de certa maneira se opõe o sociologismo do direito novo, assim como a predominância do interêsse coletivo distingue a êste, tendo em vista o predomínio do indivíduo naquele" $\left({ }^{6}\right)$.

Para uma sociedade patronal e capitalística, assentada nas bases tidas como indestrutíveis do individualismo, pode ser avaliado fàcilmente o que de terrível parecia haver em um Direito Novo, que se dispunha a violentar a vontade do cidadão, jugulando-a a princípios inflexíveis que regiam a formação dos contratos de emprêgo e que, em nome da Justiça, para equilibrar os desníveis econômicos favorecidos pelo "laissez faire, laissez passer", queria compôr um código de desigualdades jurídicas para beneficiar o humilde.

Para a consecução dêsse fim, foram necessários institutos e regras consentâneas com a idéia de solidariedade ( ${ }^{7}$ ).

Dessa maneira, com suas leis certas, com sua matéria extensa e profunda, com método adequado e particular, com uma orientação característica, o Direito do Trabalho erigiu um conjunto de princípios próprios que lhe garantem a autonomia científica, ou, para

(4) JUAN D. POZZzo, "Derecho del Trabajo", vol. I, pág. 290, 1.948, Buenos Aires. (5) BORSI e PERGOLESI, "Tratatto di Diritto del Lavoro", vol. I, pág. 16,

(7) LODOVICO BARASSI, "Il Diritto del Lavoro", 1.0 . vol., pág. $36,1.949$, Wilano. usarmos à expressão de EUGENIO PEREZ BOTIJA, a "especificidade" $\left({ }^{8}\right)$.

Como era e é uma disciplina de oposição àquele individualismo canonizado nas barricadas de Paris, sendo, ao mesmo tempo, um esfôrço de renovação dos cânones que, com sua marca, imperavam no Direito - legisladores e juízes e tratadistas a têm levantado, não poucas vêzes, à cumieira do excesso.

Procurou dar-se ao Direito do Trabalho uma fisionomia não só renovadora, mas revolucionária.

Permitir-se que o Direito do Trabalho derreta tudo quanto está assentado pela doutrina, ou melhor pela investigação abstrata e pura, na esfera dos princípios gerais - será criar não um Direito Novo, mas uma Legalização da Anarquia, a que ninguém poderá deter e que porá em risco a segurança da coletividade e do indivíduo

Ou o Direito do Trabalho é um departamento da ciência jurídica; ou não o é.

Neste caso, não tem significação técnica ou teórica. Não podesequer ser considerado em termos jurídicos.

Mas, como se viu, o Direito do Trabalho existe objetiva e subjetivamente. Não apenas nos cursos universitários, não apenas nos códigos, não apenas na vida - mas também, e isso é o que vale, na órbita dos institutos, dos princípios e dos fins.

Se a disciplina existe, se pela sua natureza é uma disciplina jurídica, se pelo seu conteúdo é uma disciplina jurídica autônoma, ela, automàticamente, está sob os postulados fundamentais do Direito.

O novo direito, por ser novo, pode riscar de seu texto as figuras desenhadas com as idéias velhas. Há idéias, porém, que, colocadas acima do tempo, são sempre novas, porque são eternas.

A êsse direito anterior e fundamental (INVREA) está sujeito o Direito do Trabalho, como também estão todos os outros ramos do direito positivo.

Queremos dizer com isso. que o Direito do Trabalho pode quebrar os princípios gerais de um direito nacional. Não pode, porém, ferir os princípios gerais da ciência jurídica.

Uma coisa é se opôr às regras de conduta dominantes em determinada sociedade. Outra coisa é se sobrepor às investigações científicas.

As premissas jurídicas do individualismo foram medularmente renovadas pelo Direito do Trabalho. $O$ cidadão ou a classe, em nenhum caso, podem ficar acima do Estado. O legislador dirá, dentro dessa noção, quais os princípios particulares da disciplina.

(8) "La Naturaleza Juridica del Derecho del Trabajo", pág. 9 e segs., 1943, Madrid. 
Ora, para uma elaboração científica da lei, o seu autor nã̃o poderá rugir aos princípios gerais do Direito em sí, assim como para apli'cação da lei elaborada não há como se fugir ao seu texto e à sua intenção.

A grande função renovadora do Direito do Trabalho, eficiente, corrosiva, inútil, estática, perante os postulados coletivistas que asseinerte, inútil, estática, perante os postulados coletivistas que asseguram a vitalidade do grupo humano. Esse ramo especial do Direito é um elemento de coesão social, jamais uma bandeira de anarquia e desintegração.

O Direito do Trabalho deriva do Direito Comum.

A origem lhe deixou cicatrizes inapagáveis.

E ao Direito comum êle volta, quando tem dúvidas, hesitações, lacunas. O pano de fundo, o grande painel, é indispensável para a perspectiva da paisagem.

No Direito Brasileiro, a lei civil é supletiva da lei trabalhista. $\mathrm{E}$ a lei processual comum preenche os imensos vazios da lei processual trabalhista $\left({ }^{9}\right)$.

O inaplicável ao direito especial que se contém no direito comum, substantivo e adjetivo, é, exaamente, a parte individualista.

Aquilo que serve de cravação para a vida em comum, os cânones fixados pela investigação teórica e que derivam, para todos os departamentos da ciência, do próprio Direito Civil êsses precisam ser reconhecidos e aceitos pelo Direito do Trabalho, sob pena de não ter êle fisionomia doutrinária, orientação filosófica, existência racional.

Como ramo da ciência jurídica, tem uma ossatura naturalmente cientifica, que lhe deve ser fortalecida.

E' preciso evitar um risco que o ameaça. A época, de pretensões políticas e de reconquistas sociais, predispõe o espírito para profanações doutrinárias, que ora revelam intenções ocultas, ora buscam maior facilidade na decisão judicial, encontrando, em qualquer caso, fácil apôio no dogma de que o Direito do Trabalho pode criar qualquer teoria, qualquer axioma, qualquer doutrina, pois é um Direito de revolução e que procura, sòmente, proteger o trabalhador.

Impõe-se, portanto, um trabalho exaustivo, para reenquadrarmos a disciplina na moldura da Teoria Geral do Direito.

A ação se deve desenvolver tanto no campo da abstração mental, da doutrina pura, como no campo prático das medidas efetivas, como aquela que se coroou na organização da Sociedade Internacional de Direito Social, sob patrocínio direto do professor CESARINO JÚNIOR. Nos congressos jurídicos, nas salas de aula, nos tribu- nais trabalhistas, nos livros, nas revistas especializadas, em todo e qualquer lugar onde se debatam os problemas do Novo Direito, abrese a ocasião propícia ao combate pela submissão do Direito do Trabalho à Teoria Geral, o que importa na sua independência em face de qualquer preconceito anti-científico.

\section{2 - A PRESCRIÇÃO COMO PRINCÍPIO UNIVERSAL DO DIREITO}

Poucos institutos possuem um caráter tão universal quanto o da PRESCRIÇÃO. De extensa significação jurídica, simbolizando a ação corrosiva do tempo sôbre os direitos inertes, é um princípio de ordem pública, invariàvelmente aceito por tôdas as legislações e definitivamente estabelecido comoprincípio geral do Direito.

Os fatos naturais circundam a sociedade, realizam-se dentro dela e, muitas vêzes, refletem na vida jurídica. O Direito não é indiferente à natureza. Ao contrário, muitas de suas figuras são pintadas por fatos cósmicos. O nascimento, que marca o início da pessoa física; a morte, que é o seu fim; o desvio do curso de água, a avulsão, o aluvião, etc.; o simples decurso do tempo; muitos outros acontecimentos decorrentes da ordem natural das coisas alteram, criam ou extinguem situaçôes umbelicadas ao Direito.

O decurso do tempo age de diversos modos na seara jurídica.

Êle cria o costume, fixa a maioridade, garante a aquisição da propriedade pelo usocapião (prescrição aquisitiva), extingue e abate direitos, etc.

A todo direito corresponde uma ação que o protege.

Quando o direito subjetivo é violado, o seu titular pode pôr em movimento o mecanismo judiciário do Estado, para reprimir o violador e aplicar-lihe a pena. Mas se o sujeito de direito, podendo exercer a faculdade de ação não a exerce; se detendo, estàticamente, o direito não o uso de modo dinâmico, para usarmos as expressões de PICCARD ${ }^{10}$ ) - a partir dêsse momento começa a correr o prazo previsto em lei, dentro do qual a sociedade lhe conserva, intacta, a possibilidade de defender seus interêsses, mas após o qual seu direito estará desamparado de qualquer poder coercitivo.

E o prazo prescricional extintivo.

O primeiro ponto é saber ( $\mathrm{e}$ isso tem interêsse imediato para a nossa tese) se a prescrição macula o direito subjetivo ou se tolhe, apenas, os meios de defesa dêsse direito, isto é, o direito à ação.

A doutrina, nesse ponto, não é pacífica.

(9) Artigos 8, parágrafo único, e 769 da Cons. das Leis do Trabalho. 
O próprio Código Civil, algumas vêzes, fala em prescrição do direito, embora, na maioria das ocasiões, se refira à prescrição das: ações correspondentes.

Há autores que defendem o ponto de vista de que o assunto perde qualquer interêsse imediato, porque um direito destituído da aça respectiva nada representa para o titular, é como se inexistisse, por não ter os meios necessários para se impor a terceiros e à coletividade. Mas, na verdade, dêsse debate puramente teórico decorrem conseqüências de ordem material e prática. A solução dêle, por outro lado, para o Direito do Trabalho, será um elemento subsidiário e valioso de interpretação da lei vigente.

Se o devedor paga o valor da dívida já prescrita por não haver. apurado a prescrição, êle não pode exigir do credor a devolução da importância que lhe entregou inadvertidamente. Se a prescrição fulminasse o direito em si, o credor teria recebido o que não lhe era mais: devido e estaria obrigado a devolvê-lo, para não se nao lhe era mais do alheio. Mas como a prescrição só atinge à ação, permanecendo íntegro, inviolado, embora estático e sem poder, o direito pròpriamente dịto, o pagamento é justo, jurídico, válido (CLÓVIS).

A corrente nacional que adota êsse ponto de vista em matéria. de prescrição é volumosa.

CLÓVIS BEVILÁCQUA assim a define: - "Prescrição é a perda da ação atribuída a um direito, e de tôda a sua capacidade defensiva, em conseqüência do não uso delas, durante um determinado espaço de tempo" (11).

CARVALHO DOS SANTOS, por seu turno, tenta definição análoga: "um modo de extinguir os direitos pela perda da ação que os assegurava, devido à inércia do credor durante um decurso de tempo determinado pela lei e que só produz seus efeitos, em regra, quando invocada por quem dela se aproveita" (12).

CÂMARA LEAL diz: "Para nós, a prescrição é - a extinção de uma ação ajuizável, em virtude da ícinção um certo lapso de tempo, na ausência de causas perclusivas de seu curso" $(13)$.

Se não há dúvida maior - ao menos na doutrina nacional sôbre essa conseqüência da prescrição, que extingue a ação protetora do direito, sem o anular, sérias controvérsias existem sôbre o seu verdadeiro fundamento.

Diversas teorias se propõem sôbre a matéria. Apanham, via de regra, aspectos externos da prescrição, meras decorrências do insti-

(11) "Teoria Geral do Direito Civil"", pág. 370, 1929, Rio de Janeiro.

(12) "Cód. Civ. Brasil. Interpretado",
3.0 .
vol., págs, 371 de Janeiro.

(13) “Da Prescrição e da Decadência”, pág. 20, 1939, São Paulo. tuto, efeitos que dela derivam. Isso, porém, não basta para explicar a natureza do instituto, sua finalidade última, sua razão de ser.

Dentre os diversos pontos de vista esposados, podemos, aqui, fazer remissão aos que, de momento, possam ter relação direta com o assunto que abordamos.

Para uns, a prescrição envolve uma proteção ao devedor (SAVIGNY); para outros, cria a presunção de renúncia ao direito (CARVALHO DOS SANTOS); para terceiros, eqüivale a uma sanção, tal "qual estipulavam as "Ordenações" (CÂMARA LEAL); etc..

Nenhum dêsses pontos de vista explica, por si só, em nosso entender, o fundamento real da prescrição.

Não se pode tê-la como medida protecionista do devedor. $\mathrm{Na}$ verdade, dela resulta um benefício para êle. Mas não existe em seu nome. O benefício é acidental e indireto. Não haveria porque proteger aquêle que deve, que viola o direito alheio, que não cumpre a obrigação assumida. A entender-se assim, a prescrição teria um fundo imoral. Não há como se auxiliar o devedor que não satisfaz o dever contraído em detrimento do credor insatisfeito.

Tampouco se deve ter na figura prescricional uma presunção de pagamento feito ou de renúncia, pelo credor, do seu direito. Em primeiro lugar, porque, seguidamente, estamos vendo credores, tolhidos pela prescrição, que tentam mover a ação para fazer valer seu direito. Em segundo lugar, porque, se houvesse renúncia do direito ou presunção de adimplemento da obrigação, nesse caso a prescrição se dirigiria contra o direito material e não contra o direito à ação, o que não ocorre, como vimos.

Numerosos monografistas e comentadores dão à figura, como fundamento, a idéia de uma pena. CÂMARA LEAL - rememorando ser êsse o ponto de vista de JOÃO MENDES JUNIOR - escreveu: "Se a prescrição priva o titular de sua ação, fazendo-o sofrer a perda de um direito, impõe-lhe, de fato, um mal. E, se essa imposição é motivada pela sua inércia, de que resultou um mal social, pelo estado antijurídico que não foi removido pela ação, representando essa inércia a falta de cumprimento de um dever social, não se poderá negar que o mal impôsto pela prescrição é, efetivamente, uma repressão do mal causado pela negligência do titular" (14).

$\mathrm{E}$ ' irrecusável que, nos efeitos da prescrição, está o prejuízo sofrido pelo credor negligente, que não dinamizou seu direito na época oportuna, trazendo, porisso, conseqüências más para a vida coletiva, que tem interêsse na pronta solução das divergências surgidas entre os que compõem o agrupamento social.

(14) Op. cit., pág. 26 
Mas é preciso que se pondere que a idéia de sanção não esgota, em absoluto, o cálice. Mesmo que se reconheça que, na prescrição efetiva, há uma pena contra o devedor cujo direito foi por ela toça - é de se ver que essa pena, como CÂMARA LEAL reconhece, se justifica pelo prejuízo social causado pela inação do titular do direito. De modo que se a prescrição se resume a uma pena (o que se admite ad argumentum) e se essa pena tem raiz no prejuízo social, é claro que a justificativa do instituto está não na sanção, mas no abalo social causado pelo credor inerte.

A conclusão, pois, é essa.

O Estado tem o máximo interêsse em que seus membros vivam em harmonia. Os choques, os litígios, os conflitos, por pequenos que sejam, abalam a estrutura social, pouco a pouco. Póem em risco o entendimento dos homens. São elementos de oposição à paz.

Com o decurso dos prazos prefixados na lei, os fatos se vão consolidando. Justos ou injustos, estratificam-se do mesmo modo. Para alterá-los depois, seria preciso quebrar essa marmorização. Isso traria permanentes abalos para a vida em comum e para a segurança das relações jurídicas. Permitir-se que um direito fôsse exercido por tempo indefinido seria criar um meio de perturbação da sociedade. "A prescrição - doutrina ESPÍNOLA - é instituída pela ordem jurídica para evitar se prolongue ou perpetue a incerteza das situacões jurídicas; atende mais ao interêsse público que ao privado" ${ }^{(15)}$.

Realçando, ainda melhor, a significação pública do instituto, CLOVIS BEVILACQUA pontifica: "A prescrição é uma regra de ordem, de harmonia e de paz, imposta pela necessidade de certeza nas relaçóes jurídicas: finis solicitudinis ad periculi litium, exclamou CÍCERO. Tolhe o impulso intempestivo do direito negligente, para permitir que se expandam as fôrças sociais, que lhe vieram ocupar o lugar vago. $E$ nem se pode alegar que há nisso uma injustiça contra o titular do direito, porque, em primeiro lugar, êle teve tempo de fazer efetivo o seu direito, e, por outro, é natural que o seu interếsse, que êle foi o primeiro a desprezar, sucumba diante do interêsse mais forte da paz social" $\left.{ }^{16}\right)$.

Sendo assim, o interêsse público não está, apenas, em se fixar um prazo firme para que o credor promova a ação contra o devedor. Se assim fôsse, pôsto em movimento o direito perante a autoridade judiciária, não mais correria o prazo prescricional. A situação ficaria eternamente em suspenso. A lide seria perpétua. Estaria frustrado o intuito harmonizador da prescrição. Há tanto prejuizo, para a

(15) "Tratado de Dir. Civ. Brasileiro", 1.0 vol., pág. 501, 1939, Rio de Ja(16) Op. cit., pág. 372. sociedade, numa ação pendente quanto num direito ainda não exercido após a sua violação.

Dêsse modo, a prescrição, no Direito Brasileiro, corre antes e depois do ajuizamento da ação.

O Código Civil, porém, deu ao credor meios de interromper a prescrição em curso, criando, ao mesmo tempo, os casos que impedem e suspendem o prazo.

Há uma diferença especial entre as causas suspensivas e as causas impedientes da prescrição. As primeiras, porque suspendem o prazo, pressupõem que, antes delas surgirem, a prescrição já começara a fluir. Valem como parêntesis, dentro do qual o tempo jurìdicamente não caminha (CARVALHO DOS SANTOS). As causas impedientes são aquelas que existem anteriormente à ação e que não deixam que o prazo comece a fluir.

As duas figuras, entretanto, foram englobadas pelo legislador comum nos mesmos dispositivos (arts. 168 a 170, do Cód. Civil).

Quando se dá a suspensão, o prazo paralisa-se pelo tempo que dura a causa suspensiva. Cessada esta, o prazo recomeça, computando-se o período anterior ao aparecimento da suspensão para cálculo e configuração do instituto prescricional.

Com a interrupção isso não acontece. Em qualquer das hipóteses do art. 172 , do Código Civil, com a alteração que lhe foi imposta pelo art. ${ }^{\circ} 166$, parágrafo $2 .^{\circ}$, do Código do Processo Civil, combinado com o Decreto-Lei n. 6.790 , de 15 de agôsto de 1.944 - a interrupção tem fôrça para inutilizar o prazo decorrido até a sua data. Mas não tem poder jurídico suficiente para suspender o tempo. A partir da interrupção, o prazo marcha, embora não se leve em linha de conta o período anterior ao advento da causa intermuptiva.

Dessa forma, não há hipótese de perpetuação da lide no direito vigente. A prescrição fulminará a ação lerda.

A doutrina dominante, encabeçada por PEDRO LESSA, CLOVIS, COSTA MANSO e outros; a jurisprudência uniforme, inclusive do Supremo Tribunal Federal - excluíram a divergência verificada entre os escritores civilistas, logo após a publicação do Código, sôbre o instituto da "perpetuação da lide".

Hoje, é princípio definitivamente fixado no Direito Brasileiro, já tomando côres de orientação histórica, que inexiste a perpetuidade das ações ajuizadas, o que era sufragado pelo direito anterior, mas foi excluido pelo Código Civil (17).

A lide eterna é incompatível com o interêsse coletivo, que exige a constituição pronta, definitiva, dos fatos e das situações juŕ́dicas, para maior firmeza das relações humanas em sociedade. (17) ARY DE $\triangle \mathrm{AEVEDO}$ FRANCO, "Prescrição Extintiva no C6́digo Civil Bra.
sileiro", pá.gs. 146 e segs., 1.950, Rio de Janeiro. 


\section{3 - A PRESCRIÇÃO NO DIREITO BRASILEIRO DO TRABALHO.}

Como vimos anteriormente, o Direito deve ser alvo de um estudo ecientífico. Para isso, é preciso cumprir o proposto por KORKOUNOV, no seu monumental "Cours de Théorie Générale du Droit": - "La science géneralise notre savoir; elle remplace le savoir immédiat, mais superficiel et concret par une connaissance plus abstraite et plus génerale; elle étudie les particularités, seulement comme des moyens necessaires à la généralisation, elle s'efforce de parvenir à des conclusions, applicables à des groupes entiers de phénomènes semblables et c'est ainsi qu'elle remplace la connaissance de tous les phénomènes particuliers, par l'étude générale des groupes" (18).

O Direito do Trabalho está, como mero departamento do Direito, subordinado a essa investigação racional.

Imperam, em seu seio, os princípios universais.

Ora, pela sua profundidade e por sua extensão, dêsses princípios, a prescrição é o mais aceito e o melhor acolhido por tôdas as legislaçôes cultas e por todos os vários direitos positivos de cada Estado.

O Direito do Trabalho, por sua natureza e por sua destinação, entroniza, também, o instituto da prescrição como regra indispensável de paz social.

Os litígios trabalhistas exigem, aliás, nesse particular, dispositi'vos rigorosos.

Como ficou constatado, na primeira parte desta exposição, o Direito do Trabalho, através da proteção dada ao empregado, procura a concórdia social, a defesa da integridade do Estado.

Como nenhum outro ramo do Direito, a legislação trabalhista reclama que as relações entre patrões e obreiros se consolidem e se constituam definitivamente, em pequeno espaço de tempo. O grande, o tormentoso problema dos dias que passam é a disputa das classes em oposição sistemática. Os dissídios individuais - singulares plúrimos - e coletivos, por diminutos que sejam, mesmo quando aparentemente desaparecidos nas dobras dos fatos que se precipitam, criam pequenas ou grandes incompatibilidades que se somam umas às outras, que se multiplicam e geram ódios universais, divergências inconciliáveis, convulsões violentas para a produçãa, para a economia, para a política, para a administração.

Os antigos processualistas, como GUSMÃO, já ponderavam que, em tôda ciência jurídica, se sente a vontade de abreviar os prazos

(18) Pág. 552, tradução fraracesa, 1:914, Paris. prescricionais, tornandoros mais rigorosos. "A tendência hodierna, de que nos dão testemunho várias legislações, segundo o proclamam os modernos escritores, é indubitàvelmente para a redução dos prazos da prescrição; porque assim o exigem as condições atuais da evolução social e econômica dos povos" $\left({ }^{19}\right)$.

Essa verificação, por certo, maiores fundamentos e justificativas encontrará no Direito do Trabalho, que aborda de frente e estuda a fundo a "questão social".

As relaçóes trabalhistas devem ser fixadas e os litígios que delas decorrem resolvidos no menor espaço de tempo possível. O interêsse do grupo assim o exige.

Está aí um dos motivos pelos quais se instituiu um processo especial para os feitos trabalhistas, eminentemente oral, econômico e, sobretudo, de uma celeridade impressionante.

Á reside, ainda, uma das razões pelas quais a Justiça do Trabalho tem um caráter conciliatório, visto que, pelo acôrdo, ao mesmo tempo que se confraternizam os representantes de duas classes, se encerra a demanda, em têrmos irrecorríveis.

Por isso, finalmente, a lei brasileira estabeleceu prazos prescricionais curtos. $\mathrm{O}$ art. ${ }^{\circ} 11$, da Consolidação, ditou, assim, a regra geral: Os direitos de reclamação perante a Justiça do Trabalho prescrevem no prazo de dois anos, SALVO DISPOSIÇÃO EM CONTRÁRIO.

A verdade, todavia, é que não existem disposições em contrário dentro da Consolidação das Leis do Trabalho.

Os prazos menores que ela indica (como, dentre outros, nos artigos 36 e 853) são prazos de decadência e não de prescrição. Aquelas regras que aparentemente se afastam do biênio marcado pelo art. ${ }^{\circ}$ 11 e contidas, por exemplo, nos artigos 119 (salário-mínimo) e 143 (férias), mantêm integralmente, no fundo, o princípio. Estabelecem, apenas, com variações, o início do prazo - dentro, aliás, da idéia ampla de que a prescrição começa a correr a partir do momento em que o direito poderia ser exercido e seu titular fica inativo.

Afirma-se, pois, sem êrro, que o prazo de dois anos impera em todo Direito Brasileiro do Trabalho, uniformizando a prescrição.

Alguns criticam a pouca extensão do prazo.

Mas assim o exige a época, que corre depressa, nas asas da técnica e na vertiginosidade da vida moderna. Assim o exige a sociedade, pela natureza de alta relevância pública das questões trabalhistas. Assim o exige a nova orientação do Direito, mencionada por GUS$\mathrm{MÃO}$ e pelos co-autores da Consolidação das Leis do Trabalho $\left({ }^{20}\right)$.

(19) "Processo 'Oivil e 'Comercial", pág. 347, 1.939, São Paulo. reito Brasileiro do Trabalho", $2 .^{\circ}$ vol., pág. $83,1.943$, Rio de Janeiro.

11 - R. D. - 3.0 Vol. 
Mas há de se considerar como extremamente lato o prazo do. art. $^{\circ} 11$, se se atentar, por exemplo, para a legislação chilena. $O$ art. 89 do Código do Trabalho daquela nação sul-americana fixa uma regra de caráter geral, que pode ser excepcionada por lei expressa, segundo a qual a prescrição de direitos e ações se efetua com o decurso do prazo insignificante de sessenta dias. E o art. ${ }^{\circ} 96$, do mesmo Código, para as ações civis por danos intencionais causados nas maquinárias e oficinas dos estabelecimentos, reduz êsse prazo pela metade ( ${ }^{21}$ ).

O caráter geral do art. $^{\circ} 11$, contra o qual não se levanta a fôrça de uma única exceção, deixa, claramente, demonstrado que NÃO EXISTEM DIREITOS TRABALHISTAS IMPRESCRITIVEIS. Todos êles estão sujeitos à fôrça destruidora do tempo, que se aproveita da inércia do titular do direito para vencê-lo.

$\hat{E}$, ainda uma vez, o interêsse social exigindo medidas drásticas: Nenhum direito trabalhista - ao contrário daqueles reconhecidos na órbita civil e relacionados por CLÓVIS BEVILÁCQUA - goza dos favores da imprescritibilidade (22). Não convém ao Estado que algum direito subjetivo possa ser exercido a qualquer tempo. Caso contrário, não haveria sossêgo nas relações trabalhistas, o que equiivale a dizer que não haveria paz nas relações sociais.

Ressalta do exposto, de sobejo, a conveniência de uma interpre: tação rigorosa em matéria de prescrição trabalhista.

Se o fundamento da prescrição fôsse uma presunção de renúncia, ou de pagamento, poder-se-ia pertender excluí-la do Direito do Trabalho, em cujo solo só medram as presunções favoráveis ao empregado, o alvo da lei protetora.

Se fôsse um benefício dado ao devedor, seria ainda razoável que só se impusesse a favor do empregado.

Se fôsse uma pena imposta ao credor negligente, talvez repugnasse ao espírito trabalhista impor sanção rude e forte contra o trabalhador ignorante e tão liberalmente defendido nas demais facetas da. Consolidação. Já dizia, porém, ALMEIDA OLIVEIRA: "A pena imposta à negligência do credor ou proprietário, ainda que imaginada. para conciliar a prescrição com a eqüidade, não deixa de ser uma coisa iníqua. O direito de cobrar ou reivindicar é uma faculdade e não uma obrigação" $\left.{ }^{23}\right)$.

Na prescrição, porém, não se busca defender o interêsse de "A" ou de "B". Não se cogita de presumir nada. Não se pensa em punir alguém. Defende-se, pura e simplesmente, o INTERESSE DA SOCIEDADE, porque "o direito creditório, exercido depois de longo.

(21) ALFREDO GAETE BERRIOS, "Manual de Derecho del Trabaj̉o", pág. 82 , 1.949, Santiago do Chile.

(23) "Da digo Civil", 1. 10 vol, pás. 477, 1916, Rio de Janeiro. tempo, leva a desordem ao seio das famílias e perturba a sociedade em suas aspirações. Tais são os motivos da prescrição em nosso conceito: E' preciso garantir a propriedade e obstar a multiplicação das demandas" (24).

Quando se declara prescrito o direito de reclamação de um empregado, não se trata de magoá-lo por sua inércia, nem de beneficiar o patrão. Trata-se de fixar, em definitivo, uma situação jurídica, o que se faz em nome do Estado. De modo que não se deve fugir a uma interpretação rigorosa do mencionado art. ${ }^{\circ} 11$, sob pena de se estar colocando o interêsse do indivíduo ou de classe acima do Estado, contrariando, portanto, o princípio informativo por excelência do Direito do Trabalho e ferindo a regra expressa do art. $.^{\circ} 8 .^{\circ}$, da Consolidação. Páginas admiráveis sôbre o assunto, em estilo sóbrio e com profundidade de conceitos, escreveu o ilustre jurista patrício NÉLIO REIS, às quais se faz, aqui, remissão $\left({ }^{25}\right)$.

Fixando o prazo, um único prazo, de índole prescricional, a Consolidação das Leis do Trabalho silenciou sôbre as particularidades que a aplicação do instituto reclama e sugere.

Se na bôca do palco não encontramos, logo, o princípio ou princípios indispensáveis à apreciação do prazo fixado em lei, é forçoso que recorramos ao painel, ao grande fundo, onde se encerram as linhas mágicas da perspectiva. Ao Direito Comum deve encaminhar-se o intérprete, nas omissões do Direito do Trabalho. Se o consolidador, portanto,se ateve a u'a mera fixação de prazo prescricional, é porque deixou os restantes ângulos do instituto entregues às regras do Direito Comum, que é fonte subsidiária e supletiva, a preencher as lacunas ocasionais ou propositadas (como, evidentemente, é o caso) do poder que elabora a lei especial.

Muitos, porém, não pensam assim.

Tribunais têm entendido que, uma vez ajuizada a ação trabalhista, a prescrição não corre mais $\left({ }^{26}\right)$.

Podemos resumir, da seguinte maneira, os argumentos que servem de apoio a êsse modo de entender:

A) A Consolidação, no discutido art. ${ }^{\circ} 11$, só se refere à prescrição do "direito de reclamar". Quer dizer que, para os direitos mate-

(24) ALNEIDA OLIVEIRA, Op. cit., págs., 20 e 21. Rio de Janeiro. Citamos, exemplificando, dois acórdãos proferidos pelo Egrégio Tribunal Regional do Trabalho da $4 .^{3}$ Regiấo, o primeiro, proferido no Proc. n. $0^{4} 45 / 47$, contra ooto do Juiz Djalma de Castilho Miaya, foi confirmado pelo Tribunal Superior do Traba 
riais, para os direitos protegidos pela reclamação, que é a ação trabalhista, não existe um prazo prescricional, isto é, não existe prescrição.

Exercida a ação dentro do prazo de dois anos, não mais haveria o risco de erosão do direito pelo decurso do tempo.

B) Do teor do art. ${ }^{\circ} 11$ ressalta uma segunda conseqüência. Se a lei diz que só prescreve o direito à reclamação e não o direito em si, uma vez ajuizada a reclamatória não pode mais êste direito prescrever. Portanto, a prescrição não corre a partir do ajuizamento da ação.

C) Se o empregado ajuizou a ação dentro do prazo hábil e, depois disso, decorreram dois anos de paralização completa do processo, é evidente que a culpa não é do empregado. Êle fêz o que lhe competia, no prazo preestabelecido. Entregou a causa ao julgamento do órgão judiciário competente. Se êste não zelou andamento célebere do feito, a responsabilidade é do órgão judicante, e não da parte. E' do Estado, não do cidadão. Seria injusto punir o trabalhador com a prescrição, quando êle nada tem a ver com a demora do processo.

Ora, êsses argumentos, tão harmoniosos na aparência, tão simples e lógicos, assentam em pressupostos falsos.

Vejamos:

A) A Consolidação, no art. $^{\circ} 11$, seguiu a melhor doutrina, quando disse que em dois anos prescreve o direito à reclamação (ação trabalhista). E' que, como vimos, a fôrça prescritiva do tempo, ao extinguir direitos, não fere o direito subjetivo em si mesmo e sim o direito à ação protetora da faculdade ofendida.

No Direito Brasileiro do Trabalho prescreve a prerrogativa de ajuizar a ação. Mas isso acontece - e é princípio uniformemente adotado - em todos os ramos do Direito. O direito em si permanece incólume, inatingido pelo tempo. A sua defesa, a ação correspondente é que se atrofia, morre, pulveriza-se pelo desuso.

A lei trabalhista, aqui, seguiu a orientação da lei comum. O Código Civil, em vários pontos, se refere à prescrição que fulmina o direito à ação. E' o exemplo do art. ${ }^{\circ} 178$, parágrafos 1 a 9.

Nem porisso se dirá que, nessas hipóteses, uma vez ajuizada a ação civil respectiva, a prescrição não correrá. Por que o dizer, então, relativamente à lei trabalhista?

B) Tampouco é certo que, ajuizada a ação, não mais corra o prazo prescricional.

Tribunais trabalhistas têm entendido, com alguma solenidade e pompa, que o simples ajuizamento da ação interrompe a prescrição e, portanto, depois de tal fato, não se pode falar em prazo prescricional.

Mas é evidente que o ajuizamento da reclamatória interrompe a prescrição.
O simples despacho do juiz ordenando a citação - mesmo quando o juiz é incompetente - interrompe a prescrição. Mas daí a concluir-se que, por essa interrupção, o prazo não corre mais, é esquecer que entre os dois casos existe um abismo.

Seria preciso que o despacho do juiz ordenando a notificação (citação) tivesse fôrça jurídica para suspender a prescrição. Mas para que tal fôsse admitido, seria necessário que a lei comum - aplicável por omissão do Direito Positivo do Trabalho - autorizasse a interpretação de que o ajuizamento da petição inicial suspende a prespretação de que ou que a lei especial assim dissesse, expressamente.

A citação, no entanto, segundo a regra de Direito Civil, apenas interrompe a prescrição. As causas suspensivas e impedientes do instituto são outras e estão catalogadas no Código, conforme, oportunamente, verificamos.

E a lei especial, no caso, silencia por completo.

Sabida a diferenca medular que, na sistemática do Direito Brasileiro, existe entre "interrupção" e "suspensão" do prazo prescricional; não sendo o ajuizamento da ação causa suspensiva, mas meramente interruptiva do dito prazo; não tendo a lei especial nada disposto em contrário ao direito comum, antes evocando-o, pelo silênposto em contrário ao direito comum, antes evocando-o, pelo sienda ação trabalhista poder para impedir o curso do prazo rigoroso, fatal e de ordem pública.

Se a lei especial houvesse dito, taxativamente, que, para efeitos trabalhistas, o ajuizamento da reclamatória suspenderia a prescrição, o debate estaria tolhido. Apesar das naturais reprimendas doutrinárias que tal dispositivo mereceria, a lei imperativa, certa ou não, deveria ser respeitada. Para isso, repetimos, seria indispensável um dispositivo taxativo, tal qual acontece no Direito Italiano $(27)$. No Direito Nacional, porém, isso não ocorre. Insistir-se, portanto, naquele ponto de vista será fugir às regras do raciocínio jurídico. Valem, aqui, as palavras de DORVAL LACERDA, que é, reconhecidamente, liberal no trato das magnas questões trabalhistas: - "Sendo damente, liberal no trato das magnas questoes trabahistas: - $S U A N O$ a prescrição princípio de ordem geral e imperativo, $A$ SUA NAO EXISTÊNCIA DEPENDE, NECESSARIAMENTE, DA EXCE-

CAOO TAXATIVA E INEQUYVOCA, SEM
FATAL E INEXORÃVELMENTE'" (28).

C) Não é certo que a parte contra a qual corre a prescrição da acão não tenha uma parcela de culpa no retardamento do processo.

Um dos deveres do que litiga em juízo é vigiar a marcha judicial (27) GIUSEPE OHIOVENDA, "Instituiçōes de Direito Processual Civil", $10^{\circ}$ vol.,
pág. 239 , tradução brasileira, 1942, São Paulo. março-abril, 1.949, pág. 8 , Rio de Janeiro. 
do feito, zelar pelo seu andamento, o que significa zelar pelos seus próprios interêsses. O autor que deixa a demanda imobilizar-se na burocracia do forum, dia a dia mais acentuada; no tuários ou no indiferentismo do próprio magistralencia dos servenpando e participando direto do próprio magistrado - está particimente, como causa eficiente do atraso do

A parte deve ficar em vigília processual permanente, lançando
mão dos meios necessários para a march pendo a prescrição na forma a marcha rápida do feito, interromtornar necessário. na forma permitida pela lei sempre que isso se

O cidadão que ajuiza a ação e que a deixa esquecida se equipara àquele que nunca a ajuizou.

Se não faz tudo para que o processo ande, vai responder por essa inércia e perderá o direito à ação, como se não a houvesse ajuizado, pelo simples decurso do espaço de tempo prefixado pela legis-
lação.

Admitindo-se, porém, ad argiumentum, que nenhuma culpa caiba à parte na procrastinação do processo - nem assim fica de pé o ar-
gumento analisado.

Como tivemos ocasião de afirmar, na palavra dos mais autorizados doutrinadores e no estudo das finalidades dêsse instituto universal, a prescrição não envolve a punição do titular negligente no to de seus direitos.

A prescrição é um princípio impositivo de ordem e de harmonia
De modo que, mesmo paralisia processual em mesmo se o empregado não tiver culpa na conseqüêencias da prescrição, que visa reclamatória, êle sofrerá as encerramento do litígio, de forma violenta à sua punição, mas ao

A ausência de culpa isentaria violenta, mas útil à comunidade. por exemplo, a suspensáo do direito de reclamar penalidades, como, do Trabalho durante seis meses, nos de reclamar perante a Justiça Consolidação. Mas nunca o livras casos dos artigos 731 e 732, da atribuiríamos a êsse inca o livraria da prescrição. Caso contrário, coletiva - um fundamento que que é um instrumento de ordem punitivo usado contra onto que a doutrina já lhe negou: o de meio seu exercício fosse, paradoxalmente, um dever.

A tese supra referida, que encontra defesa no pronunciamento de tribunais, fica, assim, removida de suas bases. Quebrados os alicerfísica, ela cairá ria" demonstra o vigor taqueles que têm sufragado a "nova teo" demonstra o vigor com que ela se está enraizando. E' preciso cortar-lhe as amarras, porque ela atrita com a lei e com as idéias básicas da ciência jurídica.

A prescrição, no Direito do Trabalho, corre antes e depois do ajuizamento da reclamatória, tal qual acontece no Direito Civil. Isso porque êste é fonte subsidiária e supletiva daquele. Não tendo o legislador especial disposto em sentido contrário ao Direito Comum e tendo silenciado, os princípios gerais da prescrição adotados no Código Civil se aplicam, por inteiro, à nossa disciplina, como a ela se aplicam, também, as regras que, posteriormente ao Código Civil, em tôrno de matéria prescricional, foram ditadas no Código de Processo - tudo com fundamento nos arts. $80^{\circ}$ e 769 , da Consolidação.

Essa interpretação tem bases sólidas.

Percorrendo a bibliografia de Direito do Trabalho, nacional e estrangeiro, não se encontram discrepâncias dignas de nota.

Sempre que se estudam pontos nevrálgicos do instituto da prescrição no Direito Brasileiro do Trabalho os autores os subordinam aos princípios gerais do Código Civil $\left({ }^{29}\right)$.

De modo que, mesmo quando interrompida, a prescrição recomeça a fluir, logo após o ato que a interrompeu. Se a ação ajuizada interrompe a prescrição e ela depois continua a contar novo prazo, é evidente que o direito à ação pode prescrever em juizo.

Não há nada de extraordinário em se evocar, para a matéria trabalhista, as noções centrais da prescrição ditadas pela legislação comum.

As legislaçôes cultas o fazem, sistemàticamente.

Basta, para confirmação da assertiva, que se ensaie um pequeno estudo de direito comparado.

E' sabido que da Itália vieram, para a legislação trabalhista brasileira, as linhas mestras e a orientação essencial. Na Itália vamos encontrar, como preceito pacífico, a remissão obrigatória feita pelo estudioso de Direito do Trabalho ao Direito Comum sempre que começa a analisar as várias facetas e os problemas da prescrição.

Segundo a notícia de LUIGI DE LITALA, os próprios prazos prescricionais do Direito do Trabalho estão marcados pelo Código $\mathrm{Ci}$ vil $\left.{ }^{(30}\right)$. Todo seu ordenamento, nesse ponto, tem aplicação ao $\mathrm{Di-}$ reito do Trabalho. GIORGIO ARDAU, no seu "Corso di Diritto del Lavoro', aborda incisivamente o assunto, endereçando o apli-

(29) Embora tocando em outros pontos, vários e notáveis ensáios publicados na

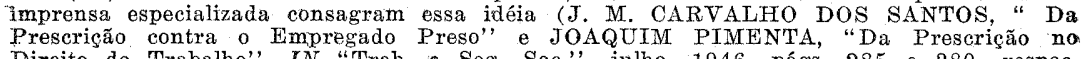
Direito do Trabalho", IN "Trab. e Seg. Soc.", julho, 1946, págs. 285 e. 280 , respece

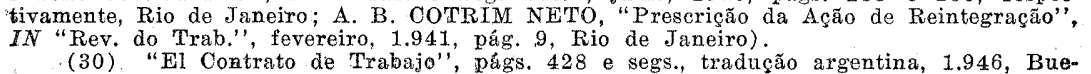
nos Aires. 
cador da lei social, diretamente, à Teoria Geral do Direito e. à chamada Ciência do Direito Privado $\left.{ }^{(31}\right)$.

$\mathrm{Da}$ mesma forma, a famosa jurista LUISA RIVA SANSEVERINO, com a invulgar autoridade que o mundo das letras jurídicas the reconhece, toca num ponto que reputamos vital. Combate ela uma pequena corrente de opinão que, na Itália, pretendia definir como imprescritíveis os direitos ecorrentes do contrato de trabalho: E' a mesma idéia que, hoje, surge no Brasil. São essas as suas palavras: - "L'applicabilità di questo ordinamento generale ai rapporti contrattuali di lavoro, anche durante la loro pendenza, è indiscutible; questo, malgrado qualche tentativo per affermare la imprescritibilità dei diritti derivanti dal contratto di lavoro, quale. conseguneza della loro irrinunciabilità, senza però tener conto che rinuncia e prescrizione sono institui non necessariamente concomitanti $\mathrm{e}$, in particolare, che la prescrizoine è l'estinzione di un diritto, non: per volontà del singolo interessato, ma per volontà dello Stato", $\left({ }^{32}\right)$.

E o já citado ARDAU relembra que ao Direito do Trabalho, em: tudo e por tudo, se aplicam as noções de causa interruptiva e causa. suspensiva da prescrição - cujos conceitos cravam seus fundamentos no Código Napoleônico ( $\left.{ }^{33}\right)$.

Dessa maneira, os princípios de ordem lata que são vigorantes: em todos os departamentos jurídicos e que exigimos sejam também por fôrça da lógica, aplicáveis ao Direito Brasileiro do Trabalho, estão consagrados, exatamente, na legislação que serviu de base e motivo para a remodelação da disciplina legal dada às relações entre nossos operários e patrões.

$\mathrm{Na}$ França, verifica-se quase exatamente o mesmo que no Brasil.

O legislador,pràticamente, remeteu o intérprete da lei especial ao texto da lei comum no tocante à prescrição. Nesta é que se encontram os fundamentos, as condições e até mesmo os prazos prescricionais. "L'article 49, liv. I, Code Travail, renvoie, purement et simplement, au Code Civil en ce qui concerne a la prescription de la créance de salaire" $\left({ }^{34}\right)$.

Na Espanha, perdura a mesma evocação ao Direito Civil ( $\left.{ }^{35}\right)$. O artigo 83 da atual "lei de contrato de trabalho" limita-se a fixar o prazo de três anos para as ações derivadas do pacto laboral $\left({ }^{36}\right)$.

(31) Pág. 313, 1.947, Milano.

(32) "Corso di Diritto del Lavoro", pág. 545, 1.941, Padova.
(33) Op. cit., páss. 314 e 315 .

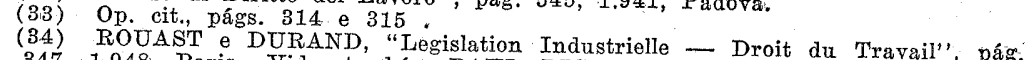
pág. 347, 1.948, Paris, Vide, também PAOL PIO \& JEAN KREAHER, "Le Nouveaus (35) EUGGNIO PEREZ BOTIJA, "Curso de Derecho del Trabajo", págs. 280
e 281, 1.948, Madrid. Madrid; PEREZ BOTIJA, "El Contrato de Trabajo" pontrato de Trabajo", pág. 355, 1.945
MENENDEZ PIDAL faz sentir que a apresentação da ação tram balhista a autoridade competente interrompe o curso do prazo pres. cricional ${ }^{37}$ ). E, segundo a notícia de SALVADOR ALARGON Y HORCAS, no Direito Espanhol, é mantida a distinção clássica entre a suspensão e a interrupção da prescrição ( $\left.{ }^{38}\right)$.

Consoante MARIO DE LA CUEVA, a jurisprudência fixou o. princípio de que o ajuizamento da demanda implica em interrupção da prescrição. Informa, ainda, o mesmo autor que os assuntos vinculados à suspensão do prazo não têm propiciado maiores debates no Direito Mexicano ( $\left.{ }^{39}\right)$. GILLERMO CABANELLAS, objetivamente, distingue, de acôrdo com a lei do México, êsses dois casos excepcionais de quebra do curso contínuo e fatal da prescrição $\left({ }^{40}\right)$.

$\mathrm{Na}$ Alemanha, a doutrina chega, abordando o assunto, a rigores excessivos. Criando o problema da caducidade dos direitos, declara "caduco" o direito que, sem estar prescrito, é exercido com grande atraso, de modo a fugir às regras normais que pautam a conduta dos que tem boa fé. Sem dúvida, é um exagero. Coloca-se o intérprete - na defesa do interêsse coletivo de sossêego entre os indivíduos - acima do próprio legislador, imobilizando direitos ainda não maculados pela prescrição. ERNEST KROTOSCHIN, escrevendo em espanhol, faz sentir: Sin embargo, la teoria de la conducidad parece incompatible en cualquier caso con el carácter forzoso y la consiguiente irrenunciabilidad de los derechos conferidos por alguna norma laboral. Para que estos derechos se extingan por expiración de un plazo, es necessaria la prescrición del derecho, pues entonces el trabajador de antemano lo adquietemporal, estipulada expressamente en el mismo momento de la creación del derecho, pues entonces el trabajador de antemano lo adquiere solo con esta limitación" $\left({ }^{41}\right)$.

Essa orientação da literutura germânica serve, de qualquer forma, para nos revelar o cuidado com que os escritores especializados se voltam para o assunto, reprimindo o uso retardatário dos direitos trabalhistas.

No Chile, a lei se limita a fixar o prazo, tal qual se verifica entre nós $\left.{ }^{42}\right)$.

A Argentina não foge, também, à orientação universal. Os MARTINEZ apontam, pela omissão da lei especial, as fontes subsidiárias como reguladoras do instituto ${ }^{(43)}$. STAFORINI, por seu turno,

(37) "Derecho Procesal Social", págs. 182 e 183, 1.947, Madrid.

(39) "Derecho Mexicano del Trbajo", 10. vol., págs. 732 e e segs., 1943, México.

(40) "IIl Derecho del Trabajo y sus Contratos", pág. 446, 1.945, Buenos Aires. Aires.

(42.) ALFREDO GAETE BERRIOS, op. cit., Idc. cit.
(43) "El Contrato de Trabajo", pág. 585, 1.945, Buenos Aires. 
pondera que o ajuizamento da ação trabalhista interrompe a prescrição $\left({ }^{44}\right)$.

Que nos demonstra, pois, êsse rápido bosquejo das disposições dominantes na legislação trabalhista dos países ocidentais que mais desenvolveram seus códigos ao operário?

- Demonstra-nos, exatamente, que a prescrição é aceita de modo invariável; que suas regras, aplicáveis ao Direito do Trabalho, estão comumente contidas na legislação comum; que não existem direitos trabalhistas imprescritíveis; que o ajuizamento da reclamatória, como de qualquer outra ação, não suspende o curso do prazo marcada na lei, interrompendo-o apenas.

Assim como não se encontra, nas nações do Ocidente, um só exemplo que favoreça o ponto de vista da corrente jurisprudencial a que nos vimos referindo - não se há de achar, dentro da doutrina brasileira, um único autor que a espose.

Se se atentar para a circunstância de existir grande divergência jurisprudencial sôbre a espécie, reconhecer-se-á, então, que a teoria por nós combatida não só perde o apôio dos princípios gerais, da lei e da doutrina, como, várias vêzes, os próprios tribunais especializados dela se afastam ( $\left.{ }^{45}\right)$. Reduz-se, pois, tão estranha doutrina a uma simples orientação assumida por alguns tribunais do país.

Mas já que, aqui e ali, reponta a teoria, é preciso julgá-la no nascedouro, antes que tome corpo e adquira a fôrça das torrentes impetuosas, que muitas vêzes se despenca das salas de julgamento do Poder Judiciário, arrastando consigo tradições, princípios impostergáveis, a palavra dos mestres e até mesmo os dispositivos da lei.

Muitos tratadistas brasileiros não se ocupam com a tese, certamente porque a consideram matéria muito simples, resolvida de modo claro pela letra do Código Civil, que está implícita na Consolidação. Mas aquêles que abordam o assunto, fazem-no com expressões sucintas, objetivas e reveladoras da exatidão de nosso modo de entender.

Mesmo antes do advento da Consolidação, a doutrina nacional já tomava êsse rumo, na palavra de BUYS DE BARROS: "Não dispôs o Decreto-Lein. ${ }^{\circ} 1.237$ sôbre a interrupção e a suspensão da prescrição na Justiça do Trabalho, PELO QUE DEVE ACEITAR-SE QUE AMBAS SÃO REGIDAS PELA NOSSA LEGISLAÇÃO CIVIL" $\left({ }^{46}\right)$

(44) "Derecho Procesal del Trabajo", pág. 365, 1.946, Buenos Aires. (45) Vide o acórdão do T.R.T. da 1.a Região e o parecer aprovado pelo Minis.
tro do Trabaltho, Tndústria e Comércio, IN ARNALDO SUSSEKIND, "Dicionário Bra.-
sileiro d Decisóes Trabalhistas", pág. 200, I948, Rio de Janeiro. Rio de "Janeiro.
Da mesma forma se pronuncia ARAUJO CASTRO: "Não tendo o decreto-lei n. ${ }^{\circ} 1.237$ disposto sôbre a interrupção e a suspensão da prescrição na Justiça do Trabalho, DEVE ENTENDER-SE QUE UMA E OUTRA SÃO REGULADAS PELO CÓDIGO CIVIL" ( ${ }^{(47) . ~}$

O eminente WALDEMAR FERREIRA, escrevendo sôbre Direito do Trabalho, esposa a mesma opinião e seu pronunciamento é um subsídio valioso, pelo renome que. conquistou no cenário das letars jurídicas do país: "A PRESCRIÇÃO PODE SER INTERROMPIDA NOS CASOS E PELA FORMA DO ART. 172 DO CÓ-

DIGO CIVIL. Pela citação do devedor, mesmo ordenada por juiz incompetente. Pelo protesto, citado o devedor. Pela apresentação do título de crédito em juízo de invenário ou em concurso de credores. 'Por qualquer ato judicial, que constitua em mora o devedor. Por qualquer ato inequívoco, ainda que extra-judicial, que importe reconhecimento do direito pelo devedor. RECOMEÇA a PRESCRICÃO INTERROMPIDA A CORRER DA DATA DO ATO OUE A INTERROMPEU, OU DO PROCESSO PARA A INTERROMPER" ( ${ }^{48}$.

Já sob o império da Consolidação das Leis do Trabalho - que em nada inovou o direito anterior - outros ilustres tratadistas especializados têm destacado, com palavras exepcionalmente eruditas, a urgência de medidas judiciais eficientes contra o prolongamento dos processos $\left({ }^{49}\right)$.

E ARNALDO SUSSEKIND, que tem a seu favor a autoridade (por ser dos mais aplaudidos escritores versados em Direito Social) bem como a responsabilidade de firmar (por ter tomado parte ativa na comissão organizadora do ante-projeto da Consolidação) adota o mesmo caminho, reduzindo nossa idéia a uma única sentença: "A prescrição pode ser interrompida POR QUALQUER DOS MEIOS ADMITIDOS EM DIREITO" - e faz referência imediata e expressa ao art. ${ }^{\circ} 172$, do Código Civil ( $\left.{ }^{50}\right)$.

Há nesse parágrafo importantíssimo do Direito Social, pois, impressionante uniformidade entre os juristas que se situam em escolas diferentes. Há pontos tão evidentes que são aceitos pelas opiniões diversas.

Nem poderia ser de outra forma.

A aceitar-se o ponto de vista que - pensamos - está sobradamente refutado, adviriam conseqüencias maléficas para o próprio trabalhador, em certas ocasiões.

(47) "Justiça do Trabalho", pág. 278, 1.941, Rio de Janeiro.
(48) "A Justica do Trabaho", 2.o vol., págs. 406. e segs., 1939 Rio de Janeiro. (49) GON FELIX GOTTSCHALK, "Norma Pública e Privada no Direito do Trabalho", págs. 237 e segss., 1944, São Paulo, 
Não se pode fugir ao dilema: Ou as causas impedientes, suspensivas e interruptivas da prescrição, previstas no Código Civil, são plicáveis ao Direito do Trabalho, por omissão da lei especial e por fôrça do art. ${ }^{\circ} 8^{\circ}$, da Consolidação - e é êsse o nosso modo de ver; ou não o são.

Mas, na segunda hipótese, ipso facto, a prescrição correrá, sem limitações, contra os incapazes definidos no art. ${ }^{\circ} .^{\circ}$, do Código Civil; contra os que estiverem a servico das Fôrças Armadas em tempo de guerra; etc.... Se o Código Civil não é aplicável, nesse ponto, ao Direito do Trabalho, então só existiria uma causa suspensiva da prescricão: o ajuizamento da reclamatória. O menor, por exemplo, poderia ver seus direitos vencidos pelo tempo.

Se a prescrição não pode correr contra o obreiro menor de dezoito anos (pois a partir dêsse limite êle é equiparado ao maior de idade ex-vi do art. 446 , da Consolidação) e se, de fato, nessas condições, o prazo não marcha, como acertadamente, afirmam SUSSEKIND, LACERDA e VIANA ( ${ }^{51}$ - é porque o Código Civil não o permite, em seu art. ${ }^{\circ} 169$, inciso I.

Seria injustiça flagrante entender-se o contrário.

Mas se, porisso, se aplicar ao Direito do Trabalho uma causa suspensiva ou impediente da prescrição, hão de ser aplicáveis, também tôdas as outras causas - suspensivas, impedientes e interruptivas - pois, evidentemente, não é possível aplicar-se um princípio fundamental que circunda o instituto e deixar de lado outros, tão fundamentais quanto aquêle, sem que as disposicões expressas da lei autorizem essa distinção, que portanto é proibida ao intérprete.

Como escolher, por que distinguir entre umas e outras se tôdas elas têm a mesma natureza, se sôbre tôdas a Consolidacão silenciou, se nenhuma é incompatível com o espírito do Direito Social?

Mais um argumento se impõe.

Aceitando-se o entendimento impugnado neste estudo, vamos concluir que, ajuizada a ação trabalhista, ela se podeá prolongar indefinidamente - um, cinco, dez anos - sem qualquer movimento processual e sem qualquer ato interruptivo da prescrição.

Uma ação com tais requisitos traça, em tôdas as linhas, a idéia de Lide Perpétua.

Como ficou anteriormente bem acentuado, a perpetuação da demanda, desde a publicação do Código Civil, é figura inaceitáve e sediça. Atualmente, em todo Direito Brasileiro, não existe, em qualquer hipótese a Lide Perpétua. Seja a causa cível, criminal ou trabalhista - ela há de ter um fim, que pode estar na sentença, que pode estar no acôrdo, que pode estar na prescrição.

(51) Op. eit, 2.0 vol, pág. 84
Mas um fim sempre ela há de ter, e dentro dos prazos marcados pela lei.

Se êsse é o quadro legal, para que o Direito do Trabalho voltasse a entronizar a Lide Perpétua - que proteja relembranças das "Ordenaçôes" - di-lo-ia expressamente o texto.

Nada há, entretanto, no Direito Positivo do Trabalho a autorizar essa revivescência. Pelo contrário. O que nêle se encontra é a preocupação constante de subordinar o interêsse dos indivíduos e das classes às exigências coletivas, inclusive através da abreviação dos prazos prescricionais afim-de que se processe logo a sedimentacão dos litígios, para benefício do interêsse geral, embora com sacrifício de direitos individuais.

Dito isso, resta concluir, com as palavras de HENRY LEVY ULLMANN:

"Le droit est un principe d'ordre. La science du droit est une sciente abstraite, toute de mos par conséquent, exigeant des définitions nettees. Cette science, la notre, autefois austère et rude, s'est bien assouplie depuis vingt ans au contact des sciences circonvoisines; soit: - contre des méthodes trop scolastiques qui risquaient de la pétrifier, une réaction était nécessaire. Mais il faut éviter tout excès. Il est temps d'accentuer, suivant nous, une certaine de logique jointe à une ferme discipline de précision, de rappeler aux genérations nauvelles qu'en depit de multiples contingences impossibles à méconnaitre et qu'il est indispensable d'observer, le juriste doit s'accoutumer, par dessus tout, à conclure et à definir.

Avons-nous tort? Avons-nous raison? Si nous avons tort, ou nous le dira" $\left({ }^{52}\right)$

\section{CONCLUSÕES}

1 - O Direito do Trabalho, como departamento autônomo do Direito, é passível de uma investigação científica e filosófica. Subordina-se às premissas fixadas pela Sociologia bem como aos princípios de ordem geral, que estão acima das ciências jurídicas particulares e que nem porisso desfiguram ou excluem os institutos e os cânones próprios dos chamados Direitos Especiais.

2 - A PRESCRICূÃO é instituto universal, princípio geral do Direito, com fundamento específico na necessidade de harmonia, paz social e fixidez das relações jurídicas concretas.

(52) "Elléments d'Introduction Générle à l'Étude des Sciences Juridiques", pág. 
3 - Por omissão da lei especial, que se limitou a estabelecer o prazo de prescrição dos direitos trabalhistas, aplicam-se-lhe os princípios dominantes no Direito Civil - fonte subsidiária - inclusive no tocante às causas impedientes, supensivas e interruptivas do prazo - prescricional.

Pelotas, em 15 de julho de 1950.

\section{RELATORIO E PARECER}

\section{Relator: HENRIQUE STODIECK}

O Professor Mozart Victor Russomano, em tese intitulada "A Prescrição no Direito do Trabalho", sustenta, com brilho e erudição, o que se segue:

1) O Direito do Trabalho, embora renovador, não pode furtar-se ao ensinamentos da Teoria Geral do Direito, devendo, por isso, submeterse aos princípios gerais e universais do direito.

2) Dentre tais princípios, universalmente aplicáveis, se destaca o instituto da prescrição, que é de ordem pública e visa estabelecer a paz social, evitando a demanda eterna.

3) A lei trabalhista apenas estabelece prazo prescricional para ajuizar a reclamação, sendo omissa quanto às demais particularidades da aplicação do instituto. Em face de semelhante omissão, cabe ao aplicador das leis protetoras do trabalho recorrer à fonte subsidiária do Direio Comum, consubstanciado no Código Civil, "inclusive no tocante às causas impedientes, suspensivas e interruptivas do prazo prescricional".

Essas, de forma resumida, as conclusões do ilustrado autor da tese, com as quais concordamos, pois que, efetivamente, o Direito do Trabalho éum ramo de fenômeno jurídico em geral, e, por outro lado é cabível a aplicação ao Direito Novo dos institutos de ordem pública do Direito Comum, desde que, como no caso em foco, compatíveis e não expressamente regulamentados de outra forma na lei especial.

Por êsses motivos, somos de parecer que a tese é de ser aprovada.

Pôrto Alegre, 15 de Agosto de 1950.

$$
\begin{aligned}
& \text { Henrique Stodieck, relator } \\
& \text { Dario de Bittencourt } \\
& \text { Magdaleno Girão Barroso } \\
& \text { Mario Seixas Aurvalle } \\
& \text { Buys de Barros }
\end{aligned}
$$

\section{INDICAÇÕES SÔBRE O INSTITUTO TRABALHISTA DAS "FÉRIAS"}

\section{Mozart Victor Russomano}

Professor da Faculdade de Direito de Pelotas (Universidade do Rio Grande do Sul). Juiz-Presidente da Junta de Conciliaça e Julgannto de Pelotas. Membro Titular da Sociedade Internacional de Direito Social.

\section{1 - GENERALIDADES}

$O$ repouso anual remunerado, que permite ao organismo do empregado um restabelecimento das fôrças físicas e mentais desgastadas na labuta profissional de todos os dias, é uma antiga aspiração obreira.

Embora seja, simultâneamente, uma de suas reivindicações mais justas, foi uma de suas últimas conquistas.

A instituição das férias é recente. Data do século em que vivemos. E só o proveito por elas trazido à vida coletiva e à vida empregatícia justifica sua rápida universalização.

Antes do aparecimento da "grande indústria", pelo elevado número de dias santificados e feriados civis, bem como pela vida pausada que os homens levavam, a idéia de descanso continuado prom porcional a cada ano de trabalho, de fato, não era urgente.

A industrialização, contudo, dinamizou a vida, abalando mais a segurança física dos que vivem no seu torvelinho, ganhando o pão com o suor do seu rosto, na fatalidade da sentença bíblica. Por outro situaçôes insalubres, dor outro novas condições de serviço, decorrentes o o trabalhador para muitas moléstias. A par de medidas protecionistas, relativas à higiene e à segurança do local medidas protecionistas, re a figura das "férias trabalhistas" em tôde trabalho, incre legislaçóes, como u'a medida que superasse e comdas as modernas legislaçóes, como u'a medida que superas dias inter pletasse ou menos longo, sem prejuízo de sua remuneração habitual. 